Studia Anglica Posnaniensia 45/1, 2009

(C) School of English, Adam Mickiewicz University, Poznań, Poland

doi: 10.2478/v10121-009-0002-9

\title{
STANCE MARKING AND REGISTER IN MIDDLE ENGLISH CHARMS
}

\author{
FRANCISCO ALONSO-ALMEIDA
}

University of Las Palmas de Gran Canaria

\begin{abstract}
This paper explores the expression of stance in a corpus of Middle English charms of the fifteenth century. All the charms have a healing function, and they are used whenever standard herbal remedies are ineffective. The sources from where the texts have been taken are various, all of them from edited printed material. The study of language use and the expression of personal attitude and evaluation have been studied earlier, both synchronically (Chafe 1986; Hunston 1994) and diachronically (Kytö 1991; Salager-Meyer - Defyves 1998). However, to my knowledge, the medieval English charm has not been the object of any previous account. This study of stance in charms has implications for language register, and shows both the relationship of the authors and their texts, and the authors and their audience.
\end{abstract}

\section{Introduction}

The charm has been frequently looked at as a cultural and ethnographical source of information, rather than as a piece of discourse with an independent status. The majority of works in the field concern with aspects related to superstitious beliefs and magical procedures, and the voice of the writer has been fully ignored. This can be the result of a bias against the charm, which is often regarded as a popular and folklorist genre in sharp contrast to other more academic genres, such as tracts. The situation has been somehow remedied by the recent contributions of Olsan (2003) and Alonso-Almeida (2008). The former focuses on those linguistic aspects that are characteristic of the charm, such as codeswitching and gibberish, whereas the latter is concerned with a complete characterisation of the genre in terms of systemic-functional linguistics.

This paper revises some aspects that have not been covered in earlier formal 
studies of the charm. This includes the study of stance marking and its implication to register. By doing this, my primary goal is to weigh the presence of the writers in their texts, as well as to analyse their positions of power in relation to their audience. These will be achieved by applying earlier descriptions of stance in academic and non-academic writing (Biber, Johansson, Leech, Conrad and Finegan 1999 - henceforward Biber et al. 1999; Biber 2004; Hyland 2000; Hyland 2001). This involves a close study of the linguistic choices developed in the texts, which may express meanings other than literal.

The diachronic study of stance is restricted to very few contributions, e.g. Biber, Conrad and Reppen (1998). The work by Taavitsainen (2001) in the medical register needs to be mentioned, since she covers specific aspects other than mood and modality. Biber (2004) also contributed to the study of stance in a multi-register corpus from a historical perspective to show that stance expressions and strategies vary across registers to the extent that, whereas some disappear, new ones emerge, and some others increase in frequency. In general, the majority of works based on historical texts, although these are not purely speaking diachronic studies, focus on modal verbs rather than on other aspects of stancetaking.

This said, the structure of the paper is as follows: Section 2 provides a description of the material surveyed for analysis, as well as a short account of earlier studies of the medieval charm. Section 3 summarises the main tenets in the study of stance, and defines frequent terminology used in its description. At this point, I also include a definition of register and metafunctions. The following section focuses on the analysis, discussion and the pragmatic interpretation of findings. Section 5 contains the conclusions.

\section{Corpus of study}

Charms in the medieval medical literature are scanty. Apart from that, the same texts are versioned innumerable times in the surviving manuscripts, and this enormously reduces the number of distinct charms from the medieval period. In my study, I have discarded similar charms for my corpus, and I concentrate on distinct ones so that we can get relevant conclusions regarding stance expressions in this genre.

All the charms used in this article are from the fifteenth century, and belong to the medical register, since all of them aim at giving therapeutic advice to restore health. The corpus amounts to nearly three thousand words taken from a variety of edited sources, such as Ogden (1938), Braekman (1986), Hunt (1990), Jones (1997), and Alonso-Almeida (2000). Table 1, below, relates editions and their manuscript sources; electronic Voigts and Kurtz cataloguing numbers are included for reference. The Latin code-switching element is pre- 
sent in almost all of the instances, but texts are mainly in Middle English. Latin passages are not considered in the present analysis to avoid erroneous conclusions for the genre in English.

Table 1. Editions and manuscripts (in square brackets a reference letter is indicated in the examples for ease of reference)

\begin{tabular}{l|c|c}
\hline \multicolumn{1}{c|}{ Editor } & Manuscript & Evk no. \\
\hline Ogden (1938) [O] & Lincoln Cathedral 91 A.5.2. & 6464.00 \\
Braekman (1986) [B] & British Library, Additional 34111 & 3664.00 \\
& Glasgow University Library, MS Hunter & 1467.00 \\
Jones (1997) [J] & 117 T.5.19 & 6453.00 \\
& Glasgow University Library, MS Hunter & 4988.00 \\
Alonso-Almeida & 185 T.8.17 & \\
(2000) [A] & British Library, Sloane 962 & 5661.00 \\
Hunt (1990) [H] & & \\
\hline
\end{tabular}

Although the texts are relatively short, sentences are complete conforming the standards of what we understand nowadays by a well-formed sentence in the English language. The contents are varied, ranging from remedies for the headache, nose bleeding, and fever to veterinary material and astrological advice for plant gathering. Topic is the criterion followed by Olsan (1992) and (2003) to group charms. Hunt (1990: 79-82) has also used topic in combination with method and discursive strategies to classify medieval charms into six groups, namely (a) prayers, invocations and other verbal formulae addressed to herbs, (b) prayers and mystical words repeated over the patient, or written or applied to some part of his body as an amulet, (c) direct conjurations or exorcisms addressed to diseases, (d) narrative charms, (e) material magic, and (f) transference of disease by a verbal formula, or a ceremony, to some animal or material object.

\section{Stancetaking and the concept of register}

Stance is used in discourse to convey information other than literal. This information is related to the expression of the speakers or writers' "personal feelings, attitudes, value judgements, or assessments" (Biber et al. 1999: 996). Studies on stance have not always been carried out under this label, and various terms have applied in specific studies of stance strategies. Thus, Huston (1994) and Huston and Thompson (2000) study evaluation, whereas Chafe (1986) and Ochs (1989) speak of evidentiality and affect, respectively. Hyland (1998: 5) uses the term hedge to refer to "the means by which writers can present a proposition as an opinion rather than a fact: items are only hedges in their epis- 
temic sense, and only then when they mark uncertainty".

Another related concept is metadiscourse. Hyland (2005: 16) agrees that metadiscourse is "a fuzzy term, often characterised as simply 'discourse about discourse' or 'talk about talk". He goes on to attempting a definition of the term by revising the literature, one that is certainly blurred with multiple, not always inclusive, interpretations of the term. He offers the following definition of metadiscourse, which is complemented with the three key metadiscourse principles (Hyland 2005: 37-38); he warns that the interpersonal concepts of stance, evaluation, and engagement overlap with metadiscourse here:

\footnotetext{
Metadiscourse is the cover term for the self-reflective expressions used to negotiate interactional meanings in a text, assisting the writer (or speaker) to express a viewpoint and engage with readers as members of a particular community.

... Underpinning this conception of metadiscourse is a functionally oriented perspective, which sees writers as conducting interaction with their readers, and their readers, and three key principles of metadiscourse (Hyland and Tse, 2004). These are:

1. that metadiscourse is distinct from propositional aspects of discourse;

2. that metadiscourse refers to aspects of the text that embody writer-reader interactions;

3. that metadiscourse refers only to relations which are internal to the discourse.
}

This definition of metadiscourse is not at odds with the one given by Biber et al. (1999), and both pursue the similar objective of unravelling information other than propositional in the text, especially expressions of interpersonal meaning. Biber et al. (1999, Chapter 12) classify stance from a semantic perspective into (a) epistemic stance ("comments on the status of information in a proposition"), (b) attitudinal stance ("[attitudinal] stance markers ... report personal attitudes or feelings"), and (c) style of speaking stance ("comments on the communication itself').

The marking of stance can be done in several ways: (a) lexical marking, (b) grammatical marking, and (c) person marking. Lexical marking relies on the evaluative lexical items, especially nouns, adjectives and verbs, whereas grammatical marking consists in the use of stance grammaticalised phenomena, which Biber et al. (1999: 969) categorize in the following devices (examples are also from the same source):

a. stance adverbials: Unfortunately, we cannot do anything.

b. stance complement clauses: I just hope that I have plugged it in properly.

c. modals and semi-modals: I might be up before you go.

d. stance noun + prepositional phrase: They deny the possibility of a death wish lurking amidst the gardens of lust.

e. premodifying stance adverb (stance adverb + adjective or noun phrase): 
I'm so happy for you. Honestly, I'm really happy for you.

As for person marking, Precht (2000: 3) defines it, as follows: "Person marking refers to first, second or third person marking of a verb or predicative adjective. Person marking identifies "grammaticalization of a subject's attitudes and opinions" (Palmer 1986: 16)". The study of person marking may therefore imply the study of the use of pronouns and the use of the passive voice, among other linguistic items.

\subsection{Register}

According to Halliday (1985a), register is related with the context of situation in which a particular communicative event takes place. The consequences for language are various, since register constrains the stylistic choices in a particular text, although genre also plays an important role here. Genre is defined as the situation of culture in which a particular communicative event is realised. Whittaker and Rojo (1999: 154) relate these two concepts and argue that, whereas register configures linguistic aspects regarding role relations, as well as syntactic and lexical selections, genre is directly related with the internal semantic organization of information. Martin (1984: 25) states that a text can be generically divided into a set of informative stages that characterise that particular genre. The association of stages determines the generic structure potential of a genre. Genre is above register in the sense that a particular genre may occur in different registers. A recipe, for instance, may belong to the medical or culinary register.

Register is described according to three variables, which in turn give way to three metafunctions. These variables are the field, the tenor and the mode, and the associated metafunctions are the ideational, the interpersonal, and the textual, respectively. Halliday (1985a and 1985b) and Eggins (1994: 54) define them as shown in the table below:

Table 2. Register variables and metafunctions

\begin{tabular}{l|l|l}
\hline Variables & \multicolumn{1}{|c|}{ Metafunction } & Linguistic selections \\
\hline $\begin{array}{l}\text { Field } \\
\text { what the language is } \\
\text { used to talk about }\end{array}$ & $\begin{array}{l}\text { Ideational: Expression of } \\
\text { experiences and any type } \\
\text { of contents }\end{array}$ & $\begin{array}{l}\text { transitivity (involv- } \\
\text { ing processes, par- } \\
\text { ticipants, and cir- } \\
\text { cumstances) }\end{array}$ \\
\hline $\begin{array}{l}\text { Mode } \\
\begin{array}{l}\text { The role language is } \\
\text { playing in the interaction }\end{array}\end{array}$ & $\begin{array}{l}\text { Interpersonal: The roles } \\
\text { of participants and how } \\
\text { actions are performed }\end{array}$ & $\begin{array}{l}\text { modality and attitu- } \\
\text { dinal lexis }\end{array}$ \\
\hline $\begin{array}{l}\text { Tenor } \\
\text { The role relationships }\end{array}$ & $\begin{array}{l}\text { Textual: The construc- } \\
\text { tion of the text }\end{array}$ & $\begin{array}{l}\text { theme-rhyme organi- } \\
\text { sation }\end{array}$ \\
\hline
\end{tabular}




\begin{tabular}{l|l}
\hline between the interactants & \\
\hline 4. Analysis of stance in Middle English charms &
\end{tabular}

This section presents the analysis of stance marking in my corpus of medieval English charms. I will first start by focusing on lexical markers, to later consider grammatical stance marking. Finally, I will concentrate on person stance marking. Although a summary of the framework for analysis has been offered in Section 3, I will complement that material with relevant information on each of the stance device categories in each of the subsections in which I have divided the analysis. Quantitative analyses are performed on the basis of English words only, being Latin excluded from counting. Gibberish words are considered however as an integral part of the English sections, since these fulfill an undeniable function in the development of the therapeutic charm.

\subsection{Lexical stance marking}

There is not much literature on lexical stance, not to say that lexical stance is completely absent from works in the field. Lexical items in a particular text may carry potential added meanings of affectiveness or evaluation in the context in which they are embedded. These expressions show the authors' attitude towards their texts and towards their audience. Although it might seem that there is some clash in the function of words showing stance either lexically or grammatically, Biber points out that these two types differ "in that [lexical stance] involves only a single proposition, rather than a stance relative to some other propositions" (Biber et al. 1999: 968). This type of stance is linguistically realised especially by means of adjectives, main verbs, or nouns. At the end of this section, I comment on the use of gibberish in charms, and its function.

The distribution of stance lexical marking in the texts under analysis shows the following results:

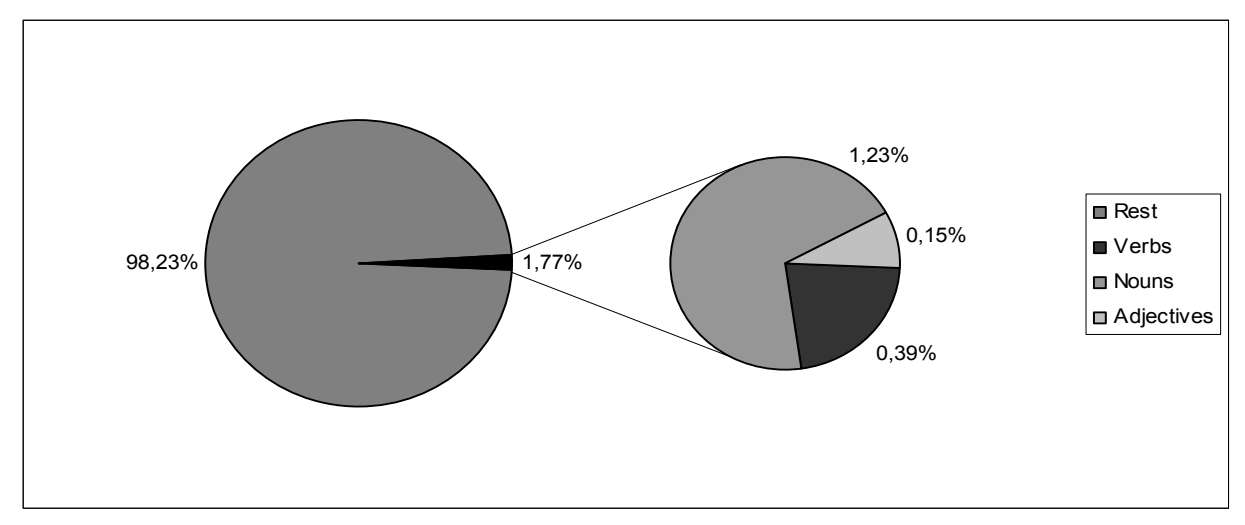


Figure 1. Distribution of lexical stance

As shown in the graph above, the number of value-laden words is small if compared with words without evident affective or evaluative meanings. The distribution of stance in lexical words illustrates that nouns are preferred to express the writers' position and emotional attitude rather than adjectives, which give the smallest representation. Lexical verbs are halfway between the other two parts of speech with six occurrences.

Nouns are certainly difficult to evaluate as stance words. Studies in the literature have classified the semantic categories of nouns showing stance, as epistemic nouns (Hyland - Milton 1997), qualifiers (Channell 1994; Biber et al. 1999), and attitudinal showing affectiveness (Biber et al. 1999). Precht (2000: 7-9) offers a review of the literature in this respect. In my corpus, many of the words fall in the group of attitude nouns within the lexical field of religion. Consider the following instances from Hunt (1990):

1) In tho honour of oure lor[d] Jesu Criste and of oure ladi seynt Mari and of sen Jop and for sent Jopes fadur soule and moder soule and all his auncetures soules, sey .iii. Pater Noster and .iii. Ave (H).

2) Save this man of this evel the which men clepe the fever $(\mathrm{H})$.

3) In the worship of five blodi teres that Our Lady lete for Cristes love, stanch, blod (H).

Many of seemingly stanceless words in the above examples have a heavy semantic load of affectiveness: honour, evel, worship, love, teres, etc. These lexical items express in one way or another the social position of the writers in terms of their beliefs. This is related to one aspect of register concerning the ideational function. During the medieval period, pagan charms were banned, and for that reason many of these texts were brought into the Christian tradition by the addition of biblical and religious elements. However, if we look at those words as indicating attitude to what is being expressed contextually, this relates another aspect of register associated with the interpersonal function. Notice, for instance, the words Cristes and love in example (3). The presence of these nouns in the prepositional phrase in which they are embedded is taken as evidence of emotion on the part of the writer.

Editorial punctuation marks that the prepositional phrase for Cristes love is part of the first clause complement of the verb lete, and so it does not affect the meaning of this first proposition. However, the absence of punctuation in the original allows for further interpretations. At least, we may deduce one in which the meaning of this prepositional phrase might be captured in the adverbial hopefully. In this case, this pattern syntactically occupies the topic position, hence framing the content of the whole proposition stanch blod. Pragmatically, 
the adverbial implies the lack of certainty towards the proposition given, and the writer cannot assert beyond doubt that the charm will heal the patient. All in all, the absence of punctuation does not permit to see the exact sense unit intended by the scribe, and so any of the values we want to endorse to (3) represent better the result of a linguistic pastime rather than the truth of the text.

Two adjectives are the total number of this word category showing stance, and these are included in the examples below:

4) So stynte the blode + thorowe the vertue of hem and the fyve woundes that he suffred + on the verray cros $(\mathrm{H})$.

5) In the worship of five blodi teres that Our Lady lete for Cristes love, stanch, blod $(\mathrm{H})$.

All the stance adjectives are given in attributive position: verray and blodi. The first one shows an evaluation about the truthfulness of the object described, whereas the second one gives information about the emotional state of the writer. Admittedly, the adjective blodi may be argued to express an aspect regarding the tears of the Virgin without any further meaning or intention. Notwithstanding, the fact that the writer decided to include this image of the Virgin is no doubt intentional. This pathetic representation of the Virgin contributes to show the author's sympathy for what he says.

Regarding verbs, these show attitudinal stance by expressing emotion or affectivity, as in the example below:

6) For the woundes that God sofrid on the crois for to buy us out of al the world, stanch, blod $(\mathrm{H})$.

The use of verbs like sofrid in declarative sentences may contribute to lexical stance (Biber et al. 1999: 968). In the particular case of this instance, the verb to suffer brings about some emotional implications on the part of the author. Other verbal forms fulfilling this function in my corpus include died 'died' and bled 'bled'.

\subsubsection{Gibberish}

The use of gibberish should be understood as a special mode of code-switching in that it refers to an unknown codified linguistic system. The function of gibberish is uncertain, but it is only used in the making of amulets and other magical preparations to cure the patient. It seems then that its main function is to activate the action of the supernatural forces to heal the sick. Gibberish appears sometimes alone, and other times together with Christian prayers. Some exam- 
ples of gibberish in my corpus are quoted below:

7) Or tak the blode of hym that bledis \& wryte in his fronte $+a+g+1+a+$ $\&$ he sal sone stanche $(\mathrm{O})$.

8) Tak \& write thir wordis in buttre or in chese \& gare hir ett it: Sator sarepo tenet opera rotas $(\mathrm{O})$.

9) Wryt hem vp on a knyf. therwyth steke a swyn \& the rennynge of the man schal be muche the lasse. thes beth the letris: $+p+G+C+p+e+u+o+$ $\mathrm{t}+\mathrm{a}+$ ges $+\mathrm{ij}+\mathrm{u}+\mathrm{iij}+$ etc. + Arisme cladauis ++++ Arisme cladauis ++++ Arisme cladauis $+++($ A).

From the point of view of register, the function of these words is to show the supremacy of the authors and their command in magical procedures. The fact that unknown and occult words are used conceals intelligibility, but also gives the false impression that the authors master a particular topic.

\subsection{Grammatical stance marking}

The study of grammatical stance in my corpus includes the following:
a. stance adverbials,
b. stance complement clauses,
c. modality,

I shall concentrate on each one of them in turn in the sections below.

\subsubsection{Stance adverbials}

Stance adverbials may appear as (a) single adverbs and adverb phrases, (b) hedges, (c) prepositional phrases, (d) adverbial clauses, and (e) comment clauses (Biber et al. 1999: 969). From the semantic point of view, they classify into epistemic, attitudinal, and style adverbs. In my corpus, the number of stance adverbials is extremely small. One case in point is:

10) He sal sone stanche $(\mathrm{O})$.

This example contains different types of stance markers, but for the moment I concentrate on the time adverb sone. This adverb indicates the temporal space in which the haemorrhage will presumably come to an end after the charm is done. In one way or another, the complete sentence seems to attest for the efficacy of the ritualistic action performed on the patient. A closer examination of this adverb in context leads us to think that the writer cannot at all guarantee 
this efficacy, and so sone is used as an epistemic adverb showing stance. Semantically, it indicates likelihood rather than certainty. If we compare this statement with other typically found in this context and with the same function, we find adverbials showing higher degrees of certainty like sothe 'surely' (Recipes 1), on warantise 'with assurance' (Recipes 2), sycurly 'surely' (Recipes 1), certeynly 'certainly' (Recipes 2). All these examples have been taken from the corpus Middle English Medical Texts (MEMT) (Taavitsainen - Pahta Mäkinen 2005), and filenames are given in brackets for reference.

The other adverbial forms showing stance in the corpus are:

11) Godde als witturly als thou wast in Bedleem born and houen in flum Jordan and made the salt watur for to stond, stwnch the blode of this man or woman $(\mathrm{H})$.

12) Alsone als scho es delyuered, tak it a-waye $(\mathrm{O})$.

13) Bynd yt betwene thy thyys \&, zif thou leuestd nauzt me, tak \& wryt hem vp on a knyf (A).

The forms and the semantics of the adverbials in the examples above are varied. Samples 1 and 2 present instances showing stance through adverbial clauses of manner. In the first case, the meaning is attitudinal and the author evaluates the way in which the proposition Godde stwnch the blode of this man or woman should be carried out. In the case of 2, the meaning is epistemic and shows imprecision as for the exact moment in which the particular action of delivering will take place. As for sample 3, the string zif thou leuestd nauzt me is formally a conditional clause serving the function of a metacomment of the author to introduce an alternative ritualistic action. This statement is epistemic and, with it, the author is judging a likely behaviour of his audience. The writer presupposes that his reader will not accept his first ritualistic action as a valid option for whatever reason, and so he decides to offer an alternative to it.

The scarcity of stance adverbs is patent throughout the corpus. However, this does not mean that there are not contexts where stance adverbs may appear. The reason for this paucity of stance adverbs in general may lie in the search of detachment on the part of the writers, and they avoid showing affectivity with their readers. In doing so, they place themselves in a position of power with respect to their audience. This lack of stance adverbials reaffirm my earlier assertion (Alonso-Almeida 2008) that despite the origin of charms may be rooted in the oral tradition at some point in time, Middle English charms are representations of a more formal written tradition. As Biber (2006: 106) points out, stance adverbs are "much more common in the spoken registers than in the written registers". All in all, I do not suggest that the Middle English charm is entirely free from oral features, but that considering all charms as popular oral 
artefacts is perhaps a strong claim not always supported by the evidence.

4.2.2. Stance complement clauses

The study of stance complement clauses is related to propositionality. Precht (2000: 38) defines propositionality as follows: "Propositionality refers to the scope over which a stance marker has influence, i.e., whether the stance marker has influence over an entire proposition, or over a single word". In the instances below, the that-clauses are framed by the verbal forms prey and worchip:

14) Lady seint Marie, I prey the in the worship of the seven cosses that thou cussid thi son on the rode $(\mathrm{H})$.

15) I worchip the fyve woundes with fyve Pater Noster that he hele this wounde $(\mathrm{H})$.

As said, the verbs prey 'pray' and worchip 'worship' frame the entire subordinate clauses. In both cases, stance is overtly attributed to the speaker by using the first person pronoun. Semantically, stance is difficult to categorise in these examples. So much so that, depending on what contextual premises are selected, they can be either epistemic or attitudinal. The writers may want to communicate their wish for the action of the supernatural to take place on the patient to get cured. In this sense, a feeling of expectancy and hope is shown, and so stance is attitudinal. However, if uncertainty is conveyed, stance is epistemic. Note that the expression of uncertainty is strongly related both (a) to the contents of the charm itself (i.e. healing through magic and the supernatural), and (b) to the impossibility to measure the intervention of the supernatural if the outcome is not as expected.

\subsubsection{Modality}

Modals affect the meaning of the complete proposition where they appear. They show two types of meaning: epistemic and deontic. Epistemic modals are "concerned with matters of knowledge or believe on which basis speakers express their judgments about state of affairs, events or actions" (Hoye 1997: 42). Deontic modals are related to the "necessity of acts in terms of which the speaker gives permission or lays an obligation for the performance of actions at some time in the future" (Hoye 1997: 43). Modals can be categorised as one type or as both. This is true in the case of the verb may which can show permission, as in You may do something, and possibility, as in It may rain.

This distinction coincides with what Biber et al. (1999: 485) call intrinsic and extrinsic: 
sic and extrinsic (also referred to as 'deontic' and 'epistemic' meanings). Intrinsic modality refers to actions and events that humans (or other agents) directly control: meanings relating to permission, obligation, or volition (or intention). Extrinsic modality refers to the logical status of events or states, usually relating to assessments of likelihood: possibility, necessity, or prediction.

There is one case in corpus where the modal verb shows an intrinsic meaning, i.e. mote 'must' as in this zerd of hasil mote joyne togidre, which expresses obligation of action in order to prove the efficacy of the ritual performed. The expanded context is given below:

16) Save this man of tis evel the which men clepe the fevre, be it hot other cold, and that in tokenyng of his hele this zerd of hasil mote joyne togidre $(\mathrm{H})$.

The other modals in the corpus of charms are shall and should, and they have extrinsic meaning, as seen in the following examples:

17) He schal be hol (A).

18) Alle ye wormes shuln gon out of his bely (J).

Both schal and shuln provide the proposition with a meaning of prediction. The writers cannot fully assert for the efficacy of the rituals, and all they can do is to predict the possible outcome of the disease if directions are followed. The fact that they use shall and should instead of must, for instance, is probably rooted in their own beliefs and perception of the world. Healing is presupposed after treatment, but cannot be fully guaranteed, perhaps because it also depends on some external supernatural forces like God himself. Actually, one of the statements containing shall mentions the grace of God as one element intervening in the success of the recovery: He chal be hole tho grace of God $(\mathrm{H})$. Taavitsainen (2001: 37) offers a different view in this respect. She classifies shall as having a deontic meaning rather than epistemic in sentences like this one. She claims that shall expresses prediction in this context, but I suppose that prediction has a sense of an expected outcome here.

From a register perspective, the massive presence of these modal verbs showing extrinsic meaning could be understood in two ways regarding the interpersonal function. A first option is concerned with the author being an authoritative voice, and so the reader considers the statement as a predicted truth rather than as a predicted possibility. A second one places the writer lower in the rank, as he is unable to realistically affirm the effectiveness of treatment.

The verb may also appears in the corpus in the following three contexts:

19) Than laye the tother stone abown als hate als it may be $(\mathrm{H})$. 
20) Holde the powder to the to the als wele als he may $(\mathrm{H})$.

21) For men that may nouzt slepe (A).

All the three occurrences of may are extrinsic. The two first ones relate to the possibility of a particular action to be. No tokens with can, or even could, are found in the corpus. The third example expresses an action that cannot be fulfilled for external uncontrolled reasons. The charm is addressed to those who suffer from insomnia.

\subsubsection{Imperatives}

Imperatives are present in all texts. Actually, this verbal form predominates all over the rest of verbal forms. This is so because the text type exemplified in charms is the instructive text type, since the charm aims at giving instruction to prepare a particular magical action or product. Thus, information is given in a list of commands that must be fulfilled by the reader in order to achieve the desired effects. Some of the imperatives have a coercive meaning, as in the following instance where the subject of the infinitive clause is the object hym for the actions ete and segge:

22) Let hym ete thys ijii hostes in thre days ffastyng \& segge iij patris \& iij aues (A).

As can be seen from the above example, the subject of the verb let is left unrealised, but it is easily retrieved from context. This makes the verbal form let occupy the thematic position, and so attention is placed on the action rather than on the performer. The use of the bold imperative, instead of a modulated or a proposal declarative command, i.e. a command realised using a modal or given in the present simple, respectively, show a hierarchic relationship of the authors with respect to their audiences.

\subsection{Person stance marking}

Precht (2000: 39) defines person marking as "the assessment of a stance marker as the speaker or writer's own stance, another person's stance, or if it is attributed to anyone". According to Biber et al. (1999: 976-978), person stance marking could be explicit (the writer is overtly identified and stance is attributed to $\mathrm{him} / \mathrm{her}$ ), implicit (the writer is not overtly indentified, but easily retrieved from context), and ambiguous (attribution of stance is unclear, and identification of authorship is not possible).

In the corpus, person marking is shown by the use of certain structures, and, in all instances, stance is attributed to the writers rather than to any third party. 
Many of the examples have been analysed before to exemplify aspects of grammatical stance, but, for ease of reference, I will quote them again in this section. Attribution of stance in the occurrences of adverbials and modals is to the writers, as in He sal sone stanche (A). In this particular example, the modal and the stance adverbial sone do not overtly attribute stance to the writer, but this information is retrieved from contextual premises. It is important to note here that, in cases like He sal sone stanche and He sall hele, the structure he sal $(l)$ allows for some degree of detachment with respect to the formulation of promise captured in these statements. The writers protect themselves from problematic overt claims of guarantee. The use of he also implies the existence of three people in the making and application of the charm: the writer, the performer, and the patient. Notice, for instance, that, in medical recipes, the use of the second person singular pronoun frequently occurs in this context, as in the example below:

23) Pro vermibus in ventre.

Take nepte, \& stampe it, \& tempre hit wyp hote wyn, \& drinke hit, when pou felyst pe wormes greuen pe, \& pou shalt be hool (Recipes 1, MEMT).

Another structure in the texts is stance complement clauses, e.g. I prey the in the worship of the seven cosses that thou cussid thi son on the rode $(\mathrm{H})$. This one overtly expresses that the stance is that of the writer what is clear by the use of the first person singular. The contents of the proposition is not threatening in the sense that no promise of efficacy is intended, only an exhortation to the divinities for helping the patient.

Attribution of stance is always to the writers in my corpus, and this is seen in the use of adverbs, modal verbs, and stance complement clauses. The function of person stance marking is to measure the degree of involvement of the writers, as well as to position the writers with respect to their own audience. In the majority of the cases, there is uncertainty as for the achievement of a particular result in the future, as shown by the use of the extrinsic modals shal 'shal' and shuln 'should' with the meaning of prediction.

\section{Conclusion}

I have examined the use of stance expressions in Middle English charms to show their effects on register variables. The general conclusion is that these expressions show two main aspects: (a) the attitude of the writers towards their texts, and (b) their relationship with their audiences. Lexical stance items illustrate the social position of writers in terms of their Christian beliefs. Gibberish seems to contradict this claim, but Christian prayers very often accompany it. Gibberish functions to enhance the view of the writers as specialists. 
Grammatical stance also helps to position authors higher in the rank. The scarcity of stance adverbs implies a lack of affectivity on the part of the writers, since we cannot trace their attitudes towards their texts and their audiences by means of this linguistic device. Both modal verbs and imperatives have an interpersonal value and they picture the writers in a higher position of power. Extrinsic modals showing prediction are seen by readers as truths rather than as predicted realities, and imperatives blatantly express commands in order to achieve a particular effect. The analysis of stance person markers reveals that attribution is always to the writers. In the cases of promises, authors tend to detach themselves from their texts by using the third person singular, as a mechanism of face-saving.

\section{REFERENCES}

Alonso-Almeida, Francisco

2000 Edition and study of a late medieval English medical receptarium. G.U.L. MS Hunter 185 (T.8.17). [Unpublished doctoral dissertation, University of Las Palmas de Gran Canaria, Spain].

2008 "The Middle English medical charms: Register, genre and text type variables", Neuphilologische Mitteilungen 109/1: 9-38.

Biber, Douglas

2004 "Historical patterns for the grammatical marking of stance: A cross-register comparison", Journal of Historical Pragmatics 5: 107-135.

2006 "Stance in spoken and written university registers", Journal of English for Academic Purposes 5: 97-116.

Biber, Douglas - Susan Conrad - Randi Reppen

1998 "Styles of stance in English: Lexical and grammatical marking of evidentiality and affect", Text 9: 93-125.

Biber, Douglas - Stig Johansson - Geoffrey Leech - Susan Conrad -Edward Finegan

1999 Longman grammar of spoken and written English. New York: Longman.

Braekman, Willy L.

1986 “A collection of medicinal recipes and charms", in: Willy L. Braekman (ed.), 113-143.

Braekman, Willy L (ed.)

1986 Studies on alchemy, diet, medecine and prognostication in Middle English. (Scripta 22). Brussels: Omirel.

Chafe, Wallace L.

1986 "Evidentiality in English conversation and academic writing", in Wallace L. Chafe Johanna Nichols (eds.), 261-272.

Channell, Joanna

1994 Vague language. Oxford: Oxford University Press.

Christie, Frances (ed.)

1984 Children writing: Reader. Geelong, Vic.: Deakin University Press.

Coulthard, Malcolm (ed.) 
1994 Advances in written text analysis. London: Routledge.

Eggins, Suzanne

1994 An introduction to systemic functional linguistics. London: Pinter.

Fortanet, Inmaculada - Santiago Posteguillo - Juan C. Palmer - Juan F. Coll

2008 Genre studies in English for academic purposes. Castellón: Servicio de Publicaciones de la Universitat Jaume I.

Gotti, Maurizio - Marina Dossena (eds.)

2001 Modality in specialized texts: Selected papers of the $1^{\text {st }}$ Cerlus conference. Bern: Peter Lang.

Halliday, Michael A. K.

1985a Spoken and written language. Geelong, Vic.: Deakin University Press.

1985b Introduction to functional grammar. Edward Arnold: London.

Hoye, Leo

1997 Adverbs and modality in English. Essex: Longman.

Hunt, Tony.

1990 Popular medicine in thirteenth-century England: Introduction and texts. Cambridge: D. S. Brewer.

Hunston, Susan.

1994 "Evaluation and organization in a sample of written academic discourse", in: Malcolm Coulthard (ed.), 191-218.

Hunston, Susan - Geoff Thompson (eds.)

2000 Evaluation in text. Oxford: Oxford University Press.

Hyland, Ken

1998 Hedging in scientific research articles. Amsterdam - Philadelphia: Benjamins.

2000 Disciplinary discourses: Social interaction in academic genres. London - New York: Longman.

2001 "Humble servants of the discipline? Self-mention in research articles", English for Specific Purposes 20/3: 207-226.

2005 Metadiscourse: Exploring interaction in writing. London: Continuum.

Hyland, Ken - John Milton

1997 "Qualification and certainty in L1 and L2 students' writing", Journal of Second Language Writing 16/2: 183-205.

Hyland, Ken - Polly Tse

2004 "Metadiscourse in academic writing: A reappraisal", Applied Linguistics 25/2: 156-177. Jones, Marie Claire.

1997 Analysis of the language and style of a late medieval medical recipe book: Glasgow University Library MS Hunter 117. [Master dissertation, Glasgow University Library].

Kytö, Merja

1991 Variation and diachrony, with early American English in focus. Frankfurt am Main: Peter Lang.

Martin, James R.

1984 “Language, genre and register”, in: Frances Christie (ed.), 21-29.

Ochs, Elinor (ed.).

1989 "The pragmatics of affect", special issue of Text 9: 1.

Ogden, Margaret Sinclair (ed.)

1938 The 'Liber de diversis medicinis' in the Thornton Manuscript (MS. Lincoln Cathedral A.5.2). (EETS, o.s. 207). London: Oxford University Press. 
Olsan, Lea T.

1992 "Latin charms of medieval England: Verbal healing in a Christian oral tradition", Oral Tradition 7: 116-42.

2003 "Charms and prayers in medieval medical theory and practice", Social History of Medicine 16/3: 343-366.

Palmer, Frank R.

1986 Mood and modality. Cambridge: Cambridge University Press.

Precht, Kristen

2000 Patterns of stance in English. [Unpublished doctoral dissertation, Northern Arizona University. Retrieved from UMI Microform 9982897].

Salager-Meyer, Francoise - G. Derives

1998 "From the gentleman's courtesy to the scientist's caution: A diachronic study of hedges in academic writing (1810-1995)", in: Inmaculada Fortanet - Santiago Posteguillo - Juan C. Palmer - Juan F. Coll (eds.), 133-171.

Taavitsainen, Irma

2001 "Evidentiality and scientific though-styles: English medical writing in Late Middle English and Early Modern English", in: Maurizio Gotti - Marina Dossena (eds.), 21-52.

Taavitsainen, Irma - Päivi Pahta - Matti Mäkinen (eds.)

2005 Middle English medical texts. Amsterdam: John Benjamins.

Voigts, Linda - Patricia Kurtz

2000 Scientific and medical writings in Old and Middle English: An electronic reference [CDROM]. Ann Arbor: Michigan University Press.

Whittaker, Rachel - Luisa Martín-Rojo

1999 "A dialogue with bureaucracy: Register, genre and information management as constraints on interchangeability", Journal of Pragmatics 31: 149-189. 